\title{
OA15.04. Accelerating the healing of bone fracture using homeopathy: a prospective, randomized double-blind controlled study
}

\author{
S Sharma ${ }^{1 *}$, N Sharma ${ }^{2}$, R Sharma $^{1}$ \\ From International Research Congress on Integrative Medicine and Health 2012 \\ Portland, Oregon, USA. 15-18 May 2012
}

\section{Purpose}

In clinical practice, homeopathy is widely used in the fracture-repair process, which accelerates the healing of fractures, enhances callus formation and reduces pain. But there is no anatomical or scientific evidence yet to prove that. Therefore, the current study was undertaken to test the efficacy of homoeopathy in bone fracture healing.

\section{Methods}

The study was conducted as a double blind randomized controlled study with 67 patients with acute non-displaced lateral malleolar fracture. Patients were recruited from the Emergency Orthopaedic department, SMS Hospital, Jaipur, India during May 2007 to May 2009. Patients were randomized to either a homoeopathy treatment $(n=34)$ or a control group $(n=33)$. All the patients received standard orthopaedic care through 12 weeks following injury. The treatment group received homoeopathic medicine on the basis of totality of symptoms and individualisation. Outcome measures include radiological assessments and functional tests for healing. Assessments were taken on 3, 6, 9 and 12 weeks.

\section{Results}

Faster healing was reported in the homeopathy group by week 9 following injury, including significant improvement in fracture line $(\mathrm{p}<0.0001)$, fracture edge $(\mathrm{p}<0.0001)$, callous formation $(\mathrm{p}<0.05)$ and fracture union $(p<0.0001)$ in comparison to placebo. There was also lower use of analgesics and less self-reported pain in the homeopathy group.

${ }^{1}$ NMP Medical Research Institute, Jaipur, India

Full list of author information is available at the end of the article

\section{Conclusion}

The study suggests that homoeopathy could enhance anatomical and functional fracture healing.

\section{Author details}

${ }^{1}$ NMP Medical Research Institute, Jaipur, India. ${ }^{2}$ Brett Research (UK), London, UK.

Published: 12 June 2012

\section{doi:10.1186/1472-6882-12-S1-061}

Cite this article as: Sharma et al:: OA15.04. Accelerating the healing of bone fracture using homeopathy: a prospective, randomized doubleblind controlled study. BMC Complementary and Alternative Medicine 2012 12(Suppl 1):061.
Submit your next manuscript to BioMed Central and take full advantage of:

- Convenient online submission

- Thorough peer review

- No space constraints or color figure charges

- Immediate publication on acceptance

- Inclusion in PubMed, CAS, Scopus and Google Scholar

- Research which is freely available for redistribution
() Biomed Central 